\title{
OECD Ülkelerinde Biyoyakıt Politikalarının Ulaşım Sektöründeki Petrol Tüketimine Etkisi
}

\author{
Hüseyin Naci Bayraç ${ }^{1}$ \\ Deniz Delican ${ }^{2}$ \\ Ahmet Tarık Karakaş3
}

OECD Ülkelerinde Biyoyakıt Politikalarının Ulaşım Sektöründeki Petrol Tüketimine Etkisi

Öz

Fosil yakıtların giderek tükenmesi, sera gazları ve iklim değişikliği, enerjide dışa bağımlılık ve enerji arz kaynaklarını çeşitlendirme ihtiyacı, biyoyakıtların önemini giderek artırmaktadır. Çalışmada, seçilmiş OECD ülkelerinde yenilenebilir enerji kaynaklarından olan biyoyakıtların ulaşım sektöründe tüketilen petrol üzerindeki etkisi, 2006- 2016 dönemine ait yıllık veriler kullanılarak, Genişletilmiş Ortalama Grup (AMG) yöntemi ile araştırılmaktadır. Analize, yardımcı değişken olarak petrol ithalat fiyatı ve ekonomik büyüme eklenmiştir. Seçilmiş $O E C D$ ülkelerinde biyoyakıt üretimi artışının ulaşım sektöründe kullanılan petrolü azalttığı sonucuna ulaşılmıştır. Bu sonuç, petrol ithal fiyatlarında yaşanacak bir artışın, ulaşım sektöründe tüketilen petrolü azaltacağı ve ülkelerin biyoyakıt gibi petrole alternatif kaynaklara yönelebileceğini göstermektedir.

Anahtar Kelimeler: Enerji Ekonomisi, Biyoyakıt Politikaları, Petrol Tüketimi, Panel Veri Analizi
The Effect of Biofuels Policies on Oil Consumption in the Transportation Sector in OECD Countries

\section{Abstract}

The increasing depletion of fossil fuels, greenhouse gases and climate change, dependence on foreign sources of energy and the need to diversify energy supply sources are increasing the importance of biofuels. In this paper, we investigate the effect of biofuels policies on oil consumed in transportation sector using the Augmented Mean Group (AMG) method for OECD countries between the periods 2006-2016. The petroleum import price and economic growth is added to the analysis as an auxiliary variable. Our findings show that the increase in biofuel production in selected OECD countries reduces the oil consumed in the transportation sector. This result shows that the increase in oil import prices will decrease the oil consumed in the transportation sector and therefore countries will switch to alternative oil sources such as biofuels.

Keywords: Energy Economics, Biofuel Policy, Oil Consumption, Panel Data Analysis.

\section{Giriş}

Yenilenebilir enerji kaynakları arasında, en fazla teknik potansiyeli olan biyokütle enerjisinin; tükenme riskinin olmaması, yerli kaynak niteliği taşıması, kolay elde edilebilirliği ve yüksek ısıl değere sahip olması nitelikleri sayesinde, enerji arzı konusunda dünya ülkelerini fosil yakıt bağımlılığından kurtarma veya azaltma olanağı bulunmaktadır. Biyokütle enerji kaynağı olarak odun, yağlı tohumlar, karbo-hidrat bitkileri, elyaf bitkileri, protein bitkileri, bitkisel- hayvansalkentsel ve endüstriyel atıklar kullanılmaktadır. Ayrıca biyokütle enerjisi kolay depolanabilirliği sayesinde diğer yenilenebilir enerji kaynaklarına göre daha avantajlıdır. Hem yerli kaynak niteliği taşıması hem de depolanmasının kolaylığı sayesinde, fosil kaynaklar açısından fakir olan ülkeler için önemli bir potansiyel enerji kaynağı niteliğindedir.

\footnotetext{
${ }^{1}$ Doç. Dr., Eskişehir Osmangazi Üniversitesi, İktisadi ve İdari Bilimler Fakültesi, İktisat Bölümü, nbayrac@ogu.edu.tr, yazar ORCID bilgisi: https://orcid.org/0000-0001-9212-987X

2 Yüksek Lisans Öğrencisi, İstanbul Üniversitesi Sosyal Bilimler Enstitüsü, Teknoloji ve Sanayi İktisadı ABD, ddenizdd.25@hotmail.com, yazar ORCID bilgisi: https://orcid.org/0000-0002-1832-3719

${ }^{3}$ Yüksek Lisans Öğrencisi, İstanbul Üniversitesi Sosyal Bilimler Enstitüsü, Teknoloji ve Sanayi İktisadı ABD, karakastarik16@gmail.com, yazar ORCID bilgisi: https://orcid.org/0000-0001-6188-4143
} 
Gelişmiş ülkelerde biyokütle yetiştiriciliği, enerji ormanlarına ve enerji bitkilerine bağlı olarak yapılmaktadır. Ormancılık ve tarıma dayalı bu yetiştiriciliğin temelinde fotosentez yatmakta ve üretimde genellikle fotosentezle hızlı büyüyen bitki türleri kullanılmaktadır. Yüksek büyüme hızına sahip ve oldukça verimsiz topraklarda bile yetişebilen enerji bitkileri üreticiliği dünya genelinde giderek önem kazanmaktadır. Günümüzde $\mathrm{C} 4$ bitki grubu olarak adlandırılan bu bitkilere dayalı, modern biyokütle enerjisi hammaddesi elde etmeyi amaçlayan ve "Enerji Tarımı" olarak tanımlanan bir tarım türü ortaya çıkmıştır.

Biyokütle; elektrik-ısı enerjisi, ulaşımda yakıt ve kimyasal hammadde olmak üzere üç ürün türüne dönüştürülebilmekte, biyokütleden elde edilen ve taşımacılıkta kullanılan enerji ise, biyoyakıt (biyoetanol ve biyodizel) olarak adlandırılmaktadır. Çalışmanın kapsamı gereği, biyokütle enerji sınıflandırması içerisinde yer alan biyoyakıtlar ele alınmıştır. Bir ülkede biyoyakıt politikalarının etkinliğini ölçebilmek için ulaştırma sektöründe petrol ürünleri tüketimini azaltıp azaltmadığına bakılmaktadır.

Bir ülkede ekonomik faaliyetler ve nüfus artışı, ulaştırma sektörü enerji talebinin belirlenmesinde anahtar rol oynamaktadır. Ekonomik büyüme, endüstriyel çıktıyı artırmakta bu da hammaddelerin sanayi üreticilerine, nihai ürünün de son kullanıcılara taşınması gerekli kılmaktadır. Şehirleşme ve kişisel gelirlerdeki artış, ulaşım amaçlı enerji talebini artıran önemli bir diğer faktördür ve gelecek yıllarda ulaşımda kullanılacak enerji talebinin hem OECD (Organisation for Economic Co-operation and Development: Ekonomik İşbirliği ve Kalkınma Örgütü) hem de OECD dışı ülkelerde artış göstermesi beklenmektedir. OECD ülkeleri, dünyanın en büyük ekonomileri arasında yer almaktadır. 36 ülkeden oluşan bu örgüte üye ülkeler, Dünya Bankası'nın sınıflandırmasına göre Macaristan, Türkiye ve Meksika hariç, gelişmiş ülkeler kategorisinde yer almakta ve bu özelliklerinden dolayı, başta petrol olmak üzere uluslararası enerji piyasalarını yönlendirme niteliğine sahiptirler. Dünyada biyoyakıt üretim ve tüketiminin önemli bir bölümü OECD ülkelerinde gerçekleştirilmektedir.

Çalışmanın amacı; seçilmiş OECD ülkelerinde, ulaşım sektöründe biyoyakıt kullanımının petrol tüketimi üzerindeki etkilerinin araştırılmasıdır. Bu amaç çerçevesinde Genişletilmiş Ortalama Grup (AMG: Augmented Mean Group) yöntemi ile 2006-2016 arası yıllık veriler kullanılarak yapılan analizde; petrol tüketimini etkileyen faktörlerden olan petrol ithalat fiyatı ve gayri safi yurt için hâsıla (GSYiH), yardımcı değişkenler olarak kullanılmıştır. Analiz, verilerine ulaşılabilen 17 OECD üyesi ülke (ABD, Almanya, Avustralya, Avusturya, Belçika, Birleşik Krallık, Finlandiya, Fransa, Güney Kore, Hollanda, İspanya, İsveç, İtalya, Kanada, Polonya, Portekiz, Türkiye) için yapılmıştır. Çalışmada; enerji tarımı kavramı ve dünyada enerji tarımı ve politikaları ele alındıktan sonra, OECD ülkelerinde uygulanan biyoyakıt politikalarına ve literatürde yer alan çalışmalara yer verilmiştir. Daha sonra da değişkenler arasındaki ilişki panel veri yöntemi ile analiz edilmiştir.

\section{Enerji Tarımı ve Politikaları}

Ekonomik büyüme ve artan nüfus küresel enerji talebini artırmış, bu durum ise insanoğlunu önemli bir enerji arz gereksinimi sorunuyla karşı karşıya getirmiştir. Yüzyıllardır alışılagelmiş fosil kaynaklı enerji tüketiminin çevreye verdiği zararlardan ve bu kaynakların kıt olmasının getirdiği zorluklardan dolayı, yenilenebilir enerji kaynaklarının ülkeler için önemi giderek artmaktadır. Enerji ihtiyacının yenilenebilir enerji kaynaklarından karşılanmaya başlanması, sürdürülebilir bir enerji kaynağı olan bitki enerjisini gündeme getirmiştir. Bitki enerjisi üretmek için bitki seçimi, bu bitkilerin yetiştirilmesi ve işlenmesi aşamalarının tümü enerji tarımı olarak 
adlandırılmaktadır. Enerji tarımı yoluyla ortaya çıkarılan her türlü enerjiye ise biyokütle enerjisi denilmektedir.

Son yıllarda biyokütle, enerji ekonomisinin önemli bir parçası haline gelmiştir. Özellikle biyokütle enerjisi kullanımının; sera gazı emisyonunu azaltması, yerel su kaynaklarında besin maddesi miktarının aşırı artması sonucu meydana gelen kirliliğin azaltılması, tarımda kullanılan zararlı kimyasalları azaltması ve yerel bir kaynak teşkil etmesi tercih edilebilirliğini giderek artırmaktadır. Bitkiler fotosentez yoluyla havadan $\mathrm{CO}_{2}$ alarak, bunu biyokütleye dönüştürürler ve böylece yakıt olarak biyokütle sadece havada bulunan karbonu serbest bırakmaktadır (Kar vd., 2017: 1569). Bitkilerin biyokütle enerjisine dönüşürken geçirdiği bu süreç çevreye zararlı faktörleri minimize etmekte ve fosil enerji kaynaklarından bu özelliği ile farklılaşmaktadır.

Biyokütle enerjisine dönüşebilen bitkiler, C4 bitkisi olarak adlandırılır. C4 tipi enerji bitkileri arasında yer alan mısır ve ay çiçeği bitkilerinin tanelerinden, şeker pancarının köklerinden, şeker kamışı, sorgum, miscanthus ve dallı darının posasından, kolza ve aspirin ise meyvelerinin değerlendirilmesiyle enerji elde edilebilmektedir. C4 tipi bitkileri; yüksek sıcaklıklarda yetişebilme, diğer bitkilere göre daha az su ihtiyacı duyma, mevsimsel kuraklığa dayanıklılık, tarım dışı arazilerde yetişebilme, yüksek biyokütle içerdiklerinden enerji üretimi için ana hammadde olması, atmosferdeki her karbondioksit molekülünü soğurabilme özelliklerine sahiptir ( http://www.yegm.gov.tr/yenilenebilir/biyokutle_enerjisi_adv.aspx).

C4 bitkilerinin üretiminin artırılması, hem doğa üzerindeki tahribatı azaltacak hem de enerji ihtiyacının giderilmesine yardımcı olacaktır. Ancak enerjiye dönüştürülecek C4 bitkilerinin seçiminde dikkat edilmesi gereken birtakım faktörler bulunmaktadır. Bu bitkiler; enerji formuna kolay ve güvenilir bir şekilde dönüşebilen, yoğun filizlenme kapasitesine sahip, kuru madde başına yüksek enerji çıktısı sağlayabilen, yıl boyunca ekilip dikilebilme özelliğine sahip, biyotik ve abiyotik strese dayanıklı, ekilebilir tarım ürünleri üretimi ile rekabet etmeyen ve çevreye zarar vermeyen bitki türlerinden oluşmalıdır (Kar vd., 2017: 1568).

Biyokütle, elektrik-ısı enerjisi, yakıt taşımacılığı ve kimyasal hammadde olmak üzere üç ürün türüne dönüştürülebilmektedir. Biyokütleden elde edilen ve taşımacılıkta kullanılan sıvı yakıtlar biyoyakıt olarak adlandırılmaktadırlar. Biyoyakıtlar üretim kaynağına göre, 1., 2. ve 3. nesil olarak sınıflandırılmaktadır. Birinci nesil biyoyakıtlar; tarımsal üretimle elde edilen ve gıda olarak da tüketilen bitkilerin hammadde olarak kullanıldığı geleneksel biyoyakıtlardır. İkinci nesil biyoyakıtlar, tarım ve orman ürünlerinin artıkları gibi gıda dışı biyokütleden ve kentsel-endüstriyel atıklardan elde edilmektedir. Üçüncü nesil biyoyakıtlar ise gıda dışı hammaddelerin kullanıldığı, gelecek yıllarda daha da geliştirilecek entegre biyorafineri teknolojileri ile genetiği değiştirilmiş tohumlar, bitkiler ve mikroalglerden üretilecek olan yakıtlardır (Bayraç ve Çemrek, 2018: 123).

Biyoyakıtlar, günümüzde yaygın olarak biyodizel ve biyoetanol biçiminde başlıca iki formda üretilmektedirler. Şeker ve nişasta (mısır) bakımından zengin mahsuller, bugün üretilen hemen hemen tüm biyoetanolün kaynağıdırlar. Şeker ve mısır dışında kullanılan diğer başlıca ürünler; buğday, sorgum, şeker pancarı, arpa, patates, manyok ve odunsu bitkilerdir. Günümüzde şeker ve nişastanın enerjiye dönüştürülmesi için gerekli teknolojik birikim oluşturulmuştur. Şeker bitkilerinden elde edilen basit şeker, etanolün içine direkt damıtılma işlemi ile enerjiye dönüştürülebilirken, nişasta bitkileri ek bir teknolojik adım ile enerjiye dönüştürülebilmektedir (BNDES ve CGEE, 2008: 65-67). Biyodizel ise, genellikle yağlı tohumlardan üretilmektedir. Bunun yanı sıra hayvansal yağ ve atıklardan da biyodizel üretilebilmekte ve petrol bazlı dizel ile karıştırılarak kullanılabilmektedir. Başlıca biyodizel üretilebilen bitkiler; kolza 
(rapeseed), kanola, ayçiçeği, soya, pamuk, aspir, keten, kenaf, kenevir, miskantusdur (Özertan, 2008: 6). Ülkeler, sahip oldukları coğrafi yapılarına ve iklim koşullarına en uygun olan bitkileri yetiştirmekte ve biyoyakıt üretmektedirler. Biyodizel üretiminde ABD ve Brezilya soya, Avrupa ülkeleri kanola, Hindistan ise jatropa bitkisini kullanmaktadır (Horuz vd., 2012: 7). Biyodizelin enerji verimliliği biyoetanolden daha yüksek ve yoğunluğu da biyoetanole göre daha fazladır.

Petrol fiyatları, dünya makroekonomik göstergeleri açısından önemli bir belirleyicidir. Bu sebeple petrol fiyatlarında yaşanan dalgalanmalar ülke ekonomilerini doğrudan etkileyebilmektedir. Petrol fiyatındaki artış veya azalışların süreleri ne kadar uzarsa ülke ekonomilerine yansımaları da o kadar etkili olmaktadır. 1973 ve 1979 yıllarında yaşanan petrol krizleri, petrol ithalatçısı olan ülkeler için önemli bir enerji arz güvenliği problemi yaratmıştır (Bayraç, 2005: 16-17). Petrol gibi diğer fosil enerji kaynakları, enerji arz güvenliği dışında çevresel sorunlara da yol açmaktadır. Özellikle fosil kaynakların yakılmasıyla ortaya çıkan sera gazı emisyonu küresel ısınmayı artırmaktadır.

2005 yılında yürürlüğe giren Kyoto Protokolü, 191 ülke ve Avrupa Birliği (AB) tarafından iklim değişikliğiyle mücadele etmek için hazırlanmıştır. Protokolün en önemli kapsamı, karayollarında taşıt kullanımından ortaya çıkan $\mathrm{CO}_{2}$ emisyonunu azaltmaktır (Bayraç, 2010: 241-245). Yaşanan bu enerji arz güvenliği ve çevresel bozulma sorunları, ülkeleri yenilenebilir enerji kaynaklarına yönlendirmiştir. Petrole alternatif bir enerji kaynağı olan biyoyakıtların tercih edilmesinin en önemli iki nedeni, yerli ve yenilenebilir enerji kaynakları olma özelliğinden kaynaklanmaktadır. Biyoyakıt üretiminin ve kullanımının yaygınlaştırılması için gerekli en önemli faktörlerden biri de devlet desteklemeleridir. OECD ülkelerinde biyoyakıt kullanımının son yıllarda artması kamu destekleme politikalarının uygulamaya konmasıyla sağlanmıştır. Biyoyakıtların petrol kökenli benzin ve motorinle rekabet edebilmesi için devlet tarafından desteklenmesi gereklidir. Bu destekleme politikaları; üretime ve tüketime yönelik desteklemeler, Ar-Ge faaliyetleri, dağıtım ve ulaştırma destekleri olarak özetlenebilmektedir (Hatunoğlu, 2010: 32-42).

Üretime yönelik başlıca destekler; biyoyakıt üretim maliyetini azaltıcı ve bununla birlikte arzı artırıcı yönde olan yardımlardır. Üretimde hammadde girdisi olarak kullanılan tarım ürünlerine verilen sübvansiyonlar, maliyeti düşürücü en önemli desteklemelerdir. Ayrıca bir diğer önemli maliyet azaltıcı destekleme de hükümet tarafından belirlenecek olan taban fiyat uygulamasıdır (Hatunoğlu, 201: 40-41). Maliyeti azaltıcı desteklerin yanı sıra üreticilerin rekabet edebilirliğini koruyabilmeleri için konulacak olan ithalat tarifeleri ve kotalar da diğer önemli destekleyici uygulamalar arasında yer almaktadır (Akalın ve Seyrekbasan, 2015: 160).

Tüketim sürecine giren her ürün için uygulanan vergi indirimi önemli bir diğer destekleme politikası niteliği taşımaktadır. Bu sebeple biyoyakıtlarda akaryakıt vergi muafiyeti uygulanması tüketimi artırıcı yönde önemli bir hükümet desteği olmaktadır (Akalın ve Seyrekbasan, 2015: 160). Biyoyakıtların dağıtım ve ulaştırma maliyetlerinin azaltılması, biyoyakıt sektörünün kalıcılığını artırmada önemli rol oynayacak başka bir politikadır. Bunun için ülkeler satış ve gelir vergilerinde indirime gitmektedirler (Hatunoğlu, 2010: 40-41).

Yeterli gelişmişlik düzeyine sahip bir teknolojik atılımın gerçekleşmemesi, bu sektörde faaliyet gösteren üreticiler için daha yüksek bir maliyete sebep olmaktadır. Bu nedenle çevreye duyarlı ve kırsal kalkınmaya önem veren ülkeler, biyoyakıt üretiminde yeni gelişmeler kaydetmek için bu sektörde istihdam yaratmak isteyen girişimcileri Ar-Ge fonlarıyla teşvik etmektedirler. Biyoyakıt üretimi, Brezilya ve ABD dışındaki ülkeler için nispeten yeni bir sektör olarak 
kabul edilmektedir. Bu sebeple öncü kabul edilebilecek olan bu iki ülkenin biyoyakıt politikaları diğer ülkelerin bu alandaki faaliyetlerine yol göstermektedir. Bu politikalarla birlikte getirilen yasal düzenlemeler biyoyakıt üretiminin artırılmasına katkı sağlamaktadır.

\section{OECD Ülkelerinde Biyoyakıt Politikaları}

Dünyadaki biyoyakıt üretimi ve tüketimi dikkate alındığında, Brezilya'nın önde gelen ülkelerden biri olduğu görülmektedir. Ülkede en çok tercih edilen biyoyakıt türü, şeker kamışının hammadde olarak kullanılmasıyla üretilen biyoetanoldür. Brezilya'da ilk olarak 1973 petrol krizinden sonra ortaya çıkan petrol kıtlığına istinaden devlet destekli biyoyakıt politikaları uygulanmaya başlanmıştır. Brezilya'da 1990'lı yıllara kadar biyoetanol politikaları devlet desteğiyle yürütülmüştür. Küreselleşmeyle birlikte liberal politikaların benimsenmesi, diğer üretimlerde olduğu gibi biyoetanol üretiminde de serbestleşmeyi kaçınılmaz kılmış ve 2000 yılında biyoetanol piyasasında liberal politikalar uygulamaya başlanmıştır.

Tablo 1: Ülkelere Göre Biyoyakıtların Diğer Yakıt Ürünlerine Harmanlama Oranları

\begin{tabular}{lcc}
\hline \multicolumn{1}{c}{ Ülkeler (Y,I) } & Biyoyakıt Türü & Harmanlama Oranı (\%) \\
\hline \hline Brezilya (2018) & Biyoetanol & $\% 27$ \\
\hline ABD (2016) & Biyoetanol \Biyodizel & $\% 15$ \\
\hline AB (2020) & Biyoetanol \Biyodizel & $\% 10$ \\
\hline Avustralya (2016) & Biyodizel & $\% 5$ \\
\hline Güney Kore (2018) & Biyodizel & $\% 3$ \\
\hline Türkiye (2014) & Biyoetanol & $\% 3$ \\
\hline
\end{tabular}

Kaynak: http://biofuelsassociation.com.au/policy/world-biofuel-policies/, (Erişim: 05.01.2019).

Tablo 1'de, ülkelere göre biyoyakıtların diğer yakıt ürünlerine harmanlama oranları verilmiştir. Tabloda en yüksek harmanlama oranına sahip olan ülkenin Brezilya olduğu görülmektedir. Yasal olarak belirlenen harmanlama oranı Brezilya'da 2018 yılı itibariyle en düşük \% 27 olarak hedeflenmiştir. Ancak ülkedeki biyoetanol kullanımı bölgelere göre farklılaşabilmekte ve bu harmanlama oranı bazı bölgelerde \% 100'e ulaşabilmektedir. Brezilya'nın etkin bir şekilde yürüttüğü biyoyakıt politikaları diğer ülkeler için örnek olmuş ve ülkeler petrol bağımlılıklarını azaltmak için bu alanda politika uygulamaya başlamışlardır.

Brezilya'dan sonra biyoyakıt politikalarının en etkin şekilde yürütüldüğü ülkelerden ikincisi ABD'dir. Ülkede hem biyoetanol hem de biyodizel üretimi ve tüketimi gerçekleştirilmektedir. Biyoetanol için hammadde olarak mısır, biyodizel için de soya fasulyesi hammadde olarak kullanılmaktadır. Dünyada biyoyakıt üretiminin en fazla yapıldığı ülke olan $A B D$, biyoyakıt politikalarına Brezilya gibi 1973 petrol kriziyle birlikte başlamıştır. ABD'de ilk olarak 1978 yılında Enerji Vergi Yasası ile biyoyakıt kullanımında \% 10 harmanlama oranı zorunlu hale getirilmiştir (Harlander, 2008: 430). Daha sonra 2005 ve 2007 yılında oluşturulan enerji yasalarıyla birlikte, enerji bağımsızığını ve güvenliğini sağlamak için biyoyakıt tüketim zorunluluğu getirilmiştir (Janda vd., 2011: 6-7). ABD'de uygulanan biyoyakıt politikalarının verimliliği, ülkenin biyoyakıt üretiminde dünyada birinci sırada yer almasında etkili olmuştur. Tablo 1'de görüldügü gibi 2016 yılı itibariyle diğer yakıt ürünlerine harmanlanan biyoyakıt oranı en az \% 15 olarak belirlenmiştir.

$A B$ biyoyakıt politikası; öncelikle, sera gazı emisyonlarının Kyoto hedefleri taahhüdünde belirtilen yükümlülükleri yerine getirmek ve $A B$ ülkelerindeki vatandaşların çevre sorunlarını ele alma konusundaki baskılarını karşılamak amacıyla tasarlanmıştır (Janda vd., 2011: 7-8). $A B^{\prime}$ de uygulanan biyoyakıt politikaları, üye ülkeler arasında çeşitli farklılıklar gösterebilmektedir. Ancak Avrupa Parlamentosunun belirlediği ve özellikle çevresel sorunların göz önüne 
alındığı bazı direktiflerde biyoyakıt kullanımına teşvikler söz konusudur. Örneğin 2003 yılında yayınlanan 2003/30/EC direktifiyle taşımacılıkta, biyoyakıt ve diğer yenilenebilir enerji kaynaklarının kullanımının yaygınlaştırılması özendirilmiştir. Ayrıca AB ülkeleri için 2005 yılında \% 2, 2010 yılında ise \% 5,75 oranları hedeflenmiştir (EC, 2003). EC 2009 yönergesinde ise, 2020 için hedeflenen ve taşımacılıkta kullanılacak biyoyakıtın harmanlama oranı \% 10 (Tablo 1) olarak tüm birlik üyesi ülkeler için zorunlu hale getirilmiştir (EC, 2009). Enerji tarımı amaçlı biyoyakıt üretiminin gıda fiyatlarını artırdığı konusunda yapılan eleştiriler üzerine, ikinci ve üçüncü nesil biyoyakıtların geliştirilmesi ve ticarileştirilmesi gerektiği ifade edilmiştir (Bayraç ve Çemrek, 2018: 125).

Güney Kore, biyoyakıt türleri içerisinde biyodizele ağırlık vermiş ülkelerden birisidir. Biyoyakıt ile ilgili ilk politikalar, 2002 yılında kamu araçlarında biyoyakıtların kullanılmasıyla gündeme gelmiştir. 2006 yılında hükümet, petrol toptancıları ve biyodizel üreticileri aralarında gönüllü bir biyoyakıt sözleşmesi imzalayarak ülke genelinde \% 0,5 harmanlama oranını otomotiv ürünlerinde kullanma kararı almıştır. Ayrıca Temmuz 2015'de yürürlüğe giren Yeni Yenilenebilir Enerji Yasası ile petrol rafinerilerine, petrol ithalat-ihracat işletmecilerine belli bir oranda yenilenebilir enerji yakıtları ile harmanlanmış petrol ürünlerini tedarik etme zorunluluğu getirilmiştir (Soon, 2015: 6-7). Güney Kore enerji ihtiyacının \% 81,4'ünü dışarıdan ithal etmektedir. Özellikle son yıllarda üretim artışının hızlandığı ülkede enerji talebinin her geçen gün artması, cari açığın da artmasına neden olmaktadır. Bu sebeple enerji talebini yerel kaynaklardan sağlayabilmek, ülke ekonomisi için büyük önem arz etmektedir.

Türkiye'de ilk olarak 2003 yılında Petrol Piyasası Kanunu'nda biyoetanol ve biyodizelin akaryakıt ürünlerine harmanlanması yer almıştır. Ayrıca Enerji Piyasası Denetleme Kurumu (EPDK) tarafından 2011 yılında, piyasada otomotiv sektöründe kullanılan benzin ürünlerine en az \% 2, 2014 yılında ise en az \% 3 oranında yerli tarım ürünlerinden elde edilen biyoetanolün harmanlaması zorunluğu getirilmiştir (OECD, 2014). Türkiye için belirlenen bu harmanlama oranı Brezilya (\% 27) ve $A B$ (\% 10) ülkeleri ile karşılaştırıldığında oldukça düşük bir düzeyde kalmaktadır. Türkiye bulunduğu iklim kuşağı sayesinde birçok biyoyakıt ürününü yetiştirebilme avantajına sahiptir. Yoğunluklu olarak biyoetanol üretimi gerçekleştirilen Türkiye'de bu ürün için gerekli hammadde şeker pancarından sağlanmaktadır. Şeker pancarı dışında mısır ve buğdayda biyoetanol üretmek için yetiştirilebilecek diğer alternatif tarım ürünleridir. Petrol rezervleri bakımından yetersiz olan Türkiye'nin yerli enerji kaynaklarının üretiminde artış gösterebilmesi, enerjide dışa bağımlıı̆̆ı azaltmak açısından oldukça önemlidir.

Biyoyakıt üretimi petrol bağımlılığını azaltması ve enerji arz güvenliğini sağlaması dışında üretimi esnasında yeni bir istihdam alanı oluşturması ve atıl durumda bulunan tarım alanlarının üretime alınmasında katkıda bulunması açısından da oldukça önemlidir. OECD üyelerinde uygulanan enerji politikaları incelendiğinde, biyoyakıt kullanımının son yıllarda zorunlu hale getirildiği görülmektedir. Yeterli teknolojik gelişmişliğin sağlanamaması ve nisbeten üretim maliyetinin fazla olması nedeniyle biyoyakıt üretiminde devlet tarafından çeşitli destekleme politikaları uygulanmaktadır. Bu destekleme politikalarında başlıca araçlar olarak vergi teşviki, Ar-Ge yardımları ve sübvansiyonlar kullanılmaktadır.

Grafik 1'de biyoyakıt üretiminin dünyadaki durumu gösterilmektedir. Dünyada üretilen biyoyakıtın büyük bir çoğunluğu OECD ülkeleri tarafından gerçekleştirilmektedir. ABD dünya biyoyakıt üretiminin \% 44'üne sahipken, $A B$ ülkeleri ise dünya üretiminin \% 16,5'ini sağlayabilmektedir. Enerji kaynakları açısından ABD'ye göre daha fakir olan $A B$ için enerji arz açığının kapatılmasında yenilenebilir enerji kaynakları ve biyoyakıtlar hayati önem taşımaktadır. 
Grafik 1: Dünyada ve OECD Ülkelerinde Biyoyakıt Üretimi (2006-2017, Milyon Ton Eşdeğer Petrol)

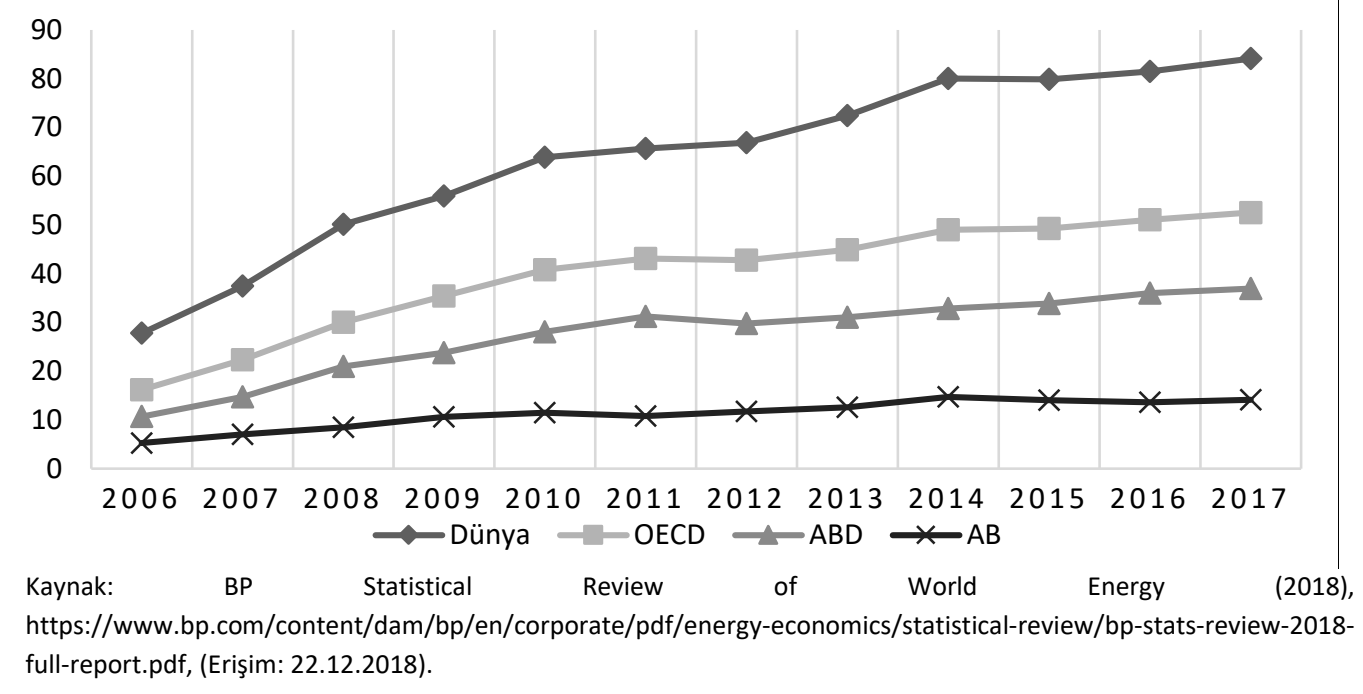

Biyoyakıtların ulaşım sektöründe kullanımının yaygınlaştırıması, bu araçlardan kaynaklanan sera gazı emisyonlarını azaltmaktadır. Ancak biyoyakıtların çevreye olan yararlarının dışında bazı zararları da bulunmaktadır. Bunlardan ilki biyoyakıt ürünlerini üretmek için kullanılan tarım alanlarının artııımasının doğal yaşamı olumsuz etkileyerek, bitki ve hayvan türleri çeşitliliğini azaltmasıdır. Diğer bir önemli sorun ise, tarımsal bir ürün olan biyoyakıtların üretimi esnasında kullanılan suyun tükenme tehlikesiyle karşı karşıya olmasıdır. Ayrıca ekilen bu tarım ürünleri için uygulanan suni gübreleme sistemleri, toprağın kirlenmesine de neden olabilmektedir. Bunlara ek olarak biyoyakıt üretimini, gıda arzını tehdit ettiği iddia edilmektedir. Biyoyakıt sağlamada C4 tipi tarım ürünleri üretim miktarının artırılması, gıda için kullanılacak olan ürünlerin arzında bir daralmaya sebep olarak gerekli besin intiyacının karşılanabilmesini zorlaştırmaktadır (Hatunoğlu, 2010: 65-90).

\section{Literatür İncelemesi}

Literatürde biyoyakıt politikalarının ulaşım sektöründe kullanılan petrol üzerindeki etkisinin araştırıldığı herhangi bir çalışma bulunmamaktadır. Yapılan çalışmalarda, biyoyakıtların daha çok ekonomik, politik ve çevresel etkileri hakkında genel değerlendirmelere yer verilmektedir. Bazı çalışmalarda ise, ekonomik büyüme ve biyoyakıt üretimi-tüketimi arasındaki ilişki incelenmiştir.

Demirbas (2009); yaptığı çalışmada biyoyakıtların ekonomik, politik ve çevresel etkilerini araştırmış ve bu çerçevede, dünyanın karşılaştığı üç riske dikkat çekmiştir. Bu riskleri yüksek yakıt fiyatları, iklim değişikliği ve hava kirliliği olarak ifade etmektedir. Biyoyakıtların (biyoetanol ve biyodizel) çevreye duyarlı olması ve petrole olan bağımlılığı azaltması gibi avantajlarından dolayı potansiyel bir enerji türü olduğunu ifade etmektedir. Çalışmanın bulguları, biyoyakıt maliyetinin petrol ürünlerine göre daha pahalı olduğunu, ancak etkin politikalar yürütüldüğünde biyoyakıtların hem çevreye hem de ülkelerin ekonomilerine katkısının yüksek olacağını yönündedir. 
Al-Mulali, Solarin ve Öztürk (2016); dağıtılmış gecikmeli otoregresif (ARDL) sınır testi yaklaşımı ve vektör hata düzeltme modeli (VECM) kullanarak, 1980-2012 yılları arasında, Brezilya'da biyoyakıt tüketimi ve ekonomik büyüme arasındaki ilişkiyi incelemişlerdir. Analiz sonuçları, biyoyakıt tüketimi ve ekonomik büyüme arasında uzun-kısa dönemli bir ilişkinin varlığını kanıtlamaktadır. Çalışmadan çıkarılan diğer bir bulgu ise, biyoyakıt tüketiminin ekonomik büyümeyi artırdığı yönündedir.

Bayraç ve Güllü (2017); ABD, Brezilya ve Almanya örnekleminde yaptıkları çalışmada, biyoyakıt üretimi, karbon emisyonu ve ekonomik büyüme arasındaki ilişkiyi, 1991-2013 yılları arasında, Johansen eş bütünleşme ve Granger nedensellik yöntemlerini kullanarak analiz etmişledir. Çalışma ulaşılan bulgular, ele alınan üç ülke için farklılıklar göstermektedir. ABD'de biyoyakıt üretiminden büyümeye ve biyoyakıt üretiminden karbon emisyonuna doğru tek yönlü bir nedensellik ilişkisi tesbit edilirken; Brezilya'da ekonomik büyümeden biyoyakıt üretimine doğru bir nedensellik belirlenmiştir. Almanya'da ise karbon emisyonu ve biyoyakıt üretimi arasında çift yönlü bir nedensellik bulunmuştur.

Reboredo vd. (2016); petrol fiyatlarında yaşanan yükseliş ve azalışların biyoyakıtlar üzerindeki etkilerini araştırmışlardır. Petrol fiyatları düştüğünde, petrol tüketiminin artacağını ve bu nedenle biyoyakıtlarda yaşanan gelişmelerin sürdürülemeyeceğini ifade etmektedirler. Bu durumda, biyoyakıtları elde edebilmek için kullanılan hammaddelerin fiyatının da düşmesi beklenmektedir. Petrol fiyatları yükseldiğinde ise biyoyakıtların kârlı hale geleceğini, bu alanda teknolojik yatırımlar artacağını ve biyoyakıt hammaddelerinin fiyatını da artacağını vurgulamışlardır.

Bildirici (2017); ekonomik büyüme, biyoyakıt tüketimi ve karbon salınımı değişkenleri arasındaki ilişkiyi, Brezilya, Çin ve ABD ülkelerinde 1985-2015 yıllarını baz alarak, ARDL ve uzun dönem tahmincilerini kullanarak analiz etmiştir. Nedensellik analizinin tespiti için Toda Yamamoto ve Rao $\mathrm{F}$ testleri uygulanmıştır. Bulgular, biyoyakıt tüketimi ve ekonomik büyüme arasında çift yönlü bir ilişkinin varlığını kanıtlamaktadır. Uzun dönemli katsayılara bakıldığında ise, ekonomik büyüme ve biyoyakıt tüketimi arasında pozitif bir ilişkinin olduğu belirlenmiştir.

Simionescu vd. (2017); ekonomik büyüme, ulaşımda kullanılan biyoyakıtlar (biyoetanol ve biyodizel) ve enerji tüketimi sonucu ortaya çıkan sera gazı emisyonu değişkenleri arasındaki ilişkiyi $A B^{\prime}$ ye üye olan 28 ülkede, dinamik panel veri ve panel vektör otoregresyon modellerini kullanarak, 2010-2015 yılları arasında analiz etmişlerdir. Çalışmanın bulguları, biyodizelin ekonomik büyüme üzerinde pozitif bir etkisi olduğunu, biyoetanolün ise ekonomik büyümeyi negatif yönde etkilediğini göstermektedir.

\section{Metot ve Bulgular}

Çalışmada, yenilenebilir enerji kaynaklarından olan biyoyakıtların, ulaşım sektöründe tüketilen petrol üzerindeki etkisi, Genişletilmiş Ortalama Grup (Augmented Mean Group-AMG) yöntemi ile seçilmiş OECD ülkelerinde tahmin edilmiştir. 2006-2016 arası yıllık veriler kullanılarak yapılan analizde; petrol tüketimini etkileyen faktörlerden olan petrol ithalat fiyatı ve gayri safi yurt için hâsıla (GSYiH) değişkenleri, yardımcı değişken olarak analize dâhil edilmiştir. Çalışmada, veri kısıtlaması nedeniyle OECD üyesi 17 ülke (ABD, Almanya, Avustralya, Avusturya, Belçika, Birleşik Krallık, Finlandiya, Fransa, Güney Kore, Hollanda, İspanya, İsveç, İtalya, Kanada, Polonya, Portekiz, Türkiye) seçilmiştir. Modellerin oluşturulması ve yorumlanması sürecinde Eviews 9 ve Stata 14 paket programlarından yararlanılmıştır. 
Tablo 2'de yer alan ulaşım sektöründe petrol ürünleri tüketimi, biyoyakıt üretimi, petrol ithalat fiyatı ve GSYiH değişkenleri sırasıyla; International Energy Agency (IEA), British Petroleum (BP), Organization of Economic Co-operation and Development (OECD) ve World Bank (WB) veri tabanlarından elde edilmiştir. Bütün değişkenler, normalizasyonu sağlamak amacıyla doğal logaritmik forma dönüştürülmüştür.

Tablo 2: Değişkenlerin Sembol ve Birim Değerleri

\begin{tabular}{ll}
\hline \hline Değişkenin Sembolü & Değişken (Birim Değeri) \\
\hline \hline LNPT & Ulaşım Sektöründe Petrol Ürünleri Tüketimi (BTEP) \\
\hline LNBY & Biyoyakıt Üretimi (BTEP) \\
\hline LNPF & Petrol İthalat Fiyatı (\$) \\
\hline LNGSYiH & Gayri Safi Yurt İçi Hâsıla (\$) \\
\hline Not: BTEP, bin ton eşdeğer petrol olarak ifade edilmektedir.
\end{tabular}

Ekonometrik uygulamalarda panel veriler, daha karmaşık davranış modelleri ile çalışabilme ve tek başına zaman seri verileri (bir ülke, bir firma vb.) veya yatay kesit (bir yıl, bir ay vb.) verileri kullanmakla mümkün olmayacak çeşitlilikte analiz yapabilme gibi imkânlar sunmasından dolayı tercih edilmektedir (Gujarati ve Porter, 2009: 593). Bu avantajları göz önüne alarak, 17 ülkeyi kapsayan bir panel veri analizinin en uygun yöntem olacağı düşünülmüştür. Panel verilerin geniş yöntem çerçevesi, amaca ve değişkenlerin yapısına göre birçok tahmincinin uygulanabilmesine izin vermektedir. Panel veri tahmincilerinden hangisinin kullanılacağına karar verebilmek için öncelikle yatay kesit bağımlılı̆̆ ve birim kökün var olup olmadığı test edilmiştir.

\subsection{Panel Verilerde Yatay Kesit Bağımlılığı ve Birim Kök Testi}

Panel verilerde uygun modelin seçilebilmesi için öncelikle değişkenlerin durağanlık dereceleri araştırılmalıdır. Birim kök testleri, yatay kesitler arasında bir ilişkinin olup olmadığı varsayımıyla birinci ve ikinci nesil birim kök testleri olarak iki gruba ayrılmaktadır. Birinci nesil panel birim kök testlerinden Im, Pesaran ve Shin (1997), Maddala ve Wu's (1999), Choi (2001) ve Levin, Lin ve Chu (2002) yatay kesitler arası bağımlılığın olmadığı varsaymaktadır. Phillips ve Sul (2003), Bai ve Ng (2004), Moon ve Perron (2004) ve Pesaran (2007) tarafından geliştirilen birim kök testleri ise, yatay kesitler arası bağımlıı̆ı̆n olduğunu varsaymaktadır. Bu bağlamda, ilk olarak yatay kesit bağımlılığı belirlenmelidir.

Makroekonomik veya finansal verilerle çalışırken, sektörler ve ülkeler arasındaki güçlü etkileşimden dolayı yatay kesit bağımlılı̆ı dikkate alınmalıdır (Westerlund ve Edgerton, 2008: 666). Küresel dünyada makroekonomik değişkenlerin birbirini etkilemediği veya bir ülkenin aldığı ekonomik kararın diğer ülkeleri etkilemediğini varsayımı ile hareket etmek, uygulanacak analizlerin güvenirliğini azaltmaktadır. Yatay kesit bağımlılığının araştırılmasında genellikle ülke sayısının (N) yıl sayısından (T) büyük olduğu (N>T) bilgisiyle testler uygulanmaktadır. Friedman (1937) ve Pesaran (2004) testleri, N>T koşulu altında yatay kesit bağımlılığını test etmede sabit ve rassal etkili modellerde kullanılabilmektedir. Bu çalışmada ( $N=17, T=11) N>T$ koşulu sağlandığından daha sağlıklı sonuçlara ulaşabilmek için Friedman (1937) ve Pesaran (2004) tarafından geliştirilen testler kullanılmıştır. Bu testlerde $\mathrm{H}_{0}$ hipotezinin kabul edilmesi yatay kesit bağımlılığının olmadığını ifade etmektedir. Yatay kesit bağımlılığını test edebilmek için öncelikle rassal ve sabit etkili regresyon modelleri tahmin edilmiştir. Model formu şu şekildedir: 
Eskişehir Osmangazi Üniversitesi ïBß Dergisi

$L N P T_{i t}=\beta_{0}+\beta_{1} L N B Y_{i t}+\beta_{2} L N P F_{i t}+\beta_{2} L N G S Y H_{i t}+u_{i t}$

i: $1,2, \ldots, 17$ (ABD, Almanya, ....., Türkiye), $\quad t: 1,2, \ldots, 11(2006, \ldots, 2016)$

Tablo 3: Friedman ve Pesaran Yatay Kesit Bağımlıı̆̆ı Testi Sonuçları

\begin{tabular}{lcc}
\hline & Sabit Etkiler Tahmincisi & \\
\hline \hline Test & İstatistik Değeri & Olasılık Değeri \\
\hline Friedman & 32,551 & $0,008^{* * *}$ \\
\hline Pesaran CD & 5,884 & $0,000^{* * *}$ \\
\hline \multicolumn{3}{l}{ Rassal Etkiler Tahmincisi } \\
\hline Friedman & İstatistik Değeri & Olasılık Değeri \\
\hline Pesaran & 32,140 & $0,009^{* * *}$ \\
\hline
\end{tabular}

Not: Olasılık değerlerinin 0,05 'den küçük olması $\mathrm{H}_{0}$ hipotezinin reddedildiğini göstermektedir. Değerlerin yanındaki *

$(* * * p<0.01, * * p<0.05)$ test sonuçlarının anlamlılığını ifade etmektedir.

Tablo 3'de Friedman (1937) ve Pesaran (2004) yatay kesit bağımlılı̆̆ı testlerinin sonuçlarına yer verilmiştir. Test sonuçları, $\mathrm{H}_{0}$ hipotezinin reddedildiğini yani yatay kesitler arasında güçlü bir ilişkinin olduğunu kanıtlamış, bu nedenle birinci nesil birim kök testlerini kullanmanın hatalı sonuçlara neden olacağı sonucuna ulaşılmıştır. Modelin doğru kurulabilmesi için ikinci nesil panel birim kök testlerinden olan Pesaran (2007) testi uygulanmıştır. Bu testte Ho hipotezinin kabul edilmesi serinin durağan olmadığını; $H_{0}$ hipotezinin reddedilmesi ise, serinin durağan olduğunu ifade etmektedir.

$H_{0}: \beta_{i}=0$ her $i$ için,

$H_{1}: \beta_{i}<0, i=1,2, \ldots, N_{1}, \beta_{i}=0 i=N_{1}+1, N_{1}+2, \ldots, N$

$\Delta y_{i t}=a_{i}+b_{i} y_{i, t-1}+c_{i} \bar{y}_{t-1}+d_{i} \Delta \bar{y}_{t}+e_{i t} \quad i=1,2, \ldots, N$ ve $t=1,2, \ldots T$

Tablo 4: Pesaran (2007) Birim Kök Testi Sonuçları

\begin{tabular}{|c|c|c|c|c|c|c|c|c|}
\hline & \multicolumn{2}{|c|}{ LNBY } & \multicolumn{2}{|c|}{ LNPT } & \multicolumn{2}{|c|}{ LNPF } & \multicolumn{2}{|c|}{ LNGSYIH } \\
\hline & Düzey & Birinci Fark & Düzey & $\begin{array}{c}\text { Birinci } \\
\text { Fark }\end{array}$ & Düzey & $\begin{array}{c}\text { Birinci } \\
\text { Fark }\end{array}$ & Düzey & $\begin{array}{c}\text { Birinci } \\
\text { Fark }\end{array}$ \\
\hline Sabit & $-3,21 * *$ & $-352 * *$ & 2,13 & $-1,89 *$ & $-2,54 * *$ & $-4,13 * *$ & 2,33 & $-3,43 * *$ \\
\hline $\begin{array}{l}\text { Sabit ve } \\
\text { Trend }\end{array}$ & $-2,43 * *$ & $-3,62 * *$ & 2,12 & $-2,40 * *$ & $-0,04$ & $-3,02 * *$ & $-0,55$ & $-0,52$ \\
\hline
\end{tabular}

Tablo 4'de, Pesaran (2007) birim kök testine yönelik sonuçlar gösterilmiştir. OECD ülkeleri için uygulanan birim kök testi sonuçlarına göre, biyoyakıt üretimi, ulaşım sektöründe tüketilen petrol, petrol fiyatı ve gayri safi yurt için hâsıla değişkenleri birinci farkları alındığında durağan hale gelmektedir.

\subsection{Yatay Kesit Bağımlılığı Durumunda Panel Eşbütünleşme Testi ve Katsayı Tahmini}

Panel verilerde değişkenler arasında uzun dönemli ilişki araştırılırken, zaman serisi veya yatay kesit verileri ile uygulanan yöntemlerden farklı şekilde ele alınmaktadır. Yatay kesitler arasında bir bağımlılık olduğunda bu durumu göz ardı eden eşbütünleşme testleri, sonuçların hatalı yorumlanmasına neden olmaktadır. Bu nedenle, çalışmada yatay kesit bağımlıı̆̆ını dikkate alan Westerlund (2007) eş bütünleşme testi uygulanmıştır. 
Bu testte $\mathrm{H}_{0}$ hipotezinin kabul edilmesi, değişkenler arasında eş bütünleşmenin olmadığını; $\mathrm{H}_{0}$ hipotezinin reddedilmesi ise, değişkenler arasında eş bütünleşme ilişkisinin var olduğunu ifade etmektedir.

Tablo 5: Westerlund (2007) Eşbütünleşme Testi Sonuçları

\begin{tabular}{llcc}
\hline İstatistik & Değer & Z Değeri & Dayanıklı (Robust) Olasılık Değerleri \\
\hline \hline $\mathrm{G}_{\mathrm{t}}$ & $-3,738$ & $-7,094$ & $0,000^{* * *}$ \\
\hline $\mathrm{G}_{\mathrm{a}}$ & $-24,39$ & $-7,744$ & $0,000^{* * *}$ \\
\hline $\mathrm{P}_{\mathrm{t}}$ & $-17,70$ & $-10,47$ & $0,000^{* * *}$ \\
\hline $\mathrm{P}_{\mathrm{a}}$ & $-25,05$ & $-11,11$ & $0,000^{* * *}$ \\
\hline
\end{tabular}

Not: Değerlerin yanındaki * $(* * * p<0.01)$ anlamlılığı ifade etmektedir.

Westerlund (2007), yatay kesitler arası bağımlılık tespit edildiğinde standart olasılık değerleri yerine bootstrap testleri ile elde edilen dayanıklı (robust) olasılık değerlerinin dikkate alınmasını önermektedir. Tablo 5'de yer alan eş bütünleşme testi sonuçları, $\mathrm{H}_{0}$ hipotezinin reddedildiğini, ulaşım sektöründe kullanılan petrol tüketimi ve biyoyakıt üretimi değişkenleri arasında uzun dönemli bir ilişkinin varlığı göstermektedir.

Seçilmiş OECD ülkelerinde, biyoyakıt üretiminin ulaşım sektöründe tüketilen petrol üzerindeki etkisini tahmin etmek için Genişletilmiş Ortalama Grup (AMG) yöntemi kullanılmıştır. Bu yöntemin tercih edilme sebebi, yatay kesit bağımlılığını dikkate alan modern bir tahminci olması ve ortalama katsayıların yanı sıra ülkelere özgü katsayıları görüntüleyebilme imkânı sağlamasıdır. Eberhardt ve Bond (2009) tarafından geliştirilen AMG tahmincisi, Monte Carlo simülasyonunu kullanmakta ve ortak dinamik etkiler (common dynamic effect) değişkeninin analize dâhil edilmesiyle yatay kesit bağımlı̆̆ını dikkate almaktadır.

Eberhardt ve Bond (2009) tarafından geliştirilen model şu şekildedir:

$y_{i t}=\beta_{i}^{\prime} \boldsymbol{x}_{i t}+u_{i t} \quad u_{i t}=\alpha_{i}+\lambda_{i}^{\prime} f_{t}+\varepsilon_{i t}$

$x_{m i t}=\pi_{m i}+\delta_{m i}^{\prime} g_{m t}+\rho_{1 m i} f_{1 m t}+\ldots+\rho_{n m i} f_{n m t}+v_{m i t}$

$m=1, \ldots, k$ ve $f_{\text {.mt }} \subset f_{t}$

$f_{t}=\varphi^{\prime} f_{t-1}+\varepsilon_{t} \quad v e \quad g_{t}=\kappa^{\prime} g_{t-1}+\varepsilon_{t}$

Denklem 3'de $\boldsymbol{x}_{\boldsymbol{i} \text { it }}$ gözlenebilir değişkenlerin bir vektörüdür. $\alpha_{i}$ gruba özel sabit etkileri, $f_{t}$ grupları etkileyen ortak faktörleri, $\lambda_{i}$ ülkeye özgü faktör yüklerini, Denklem $4^{\prime}$ de ise $m=$ $1, \ldots, k \mathrm{k}$ tane gözlemlenebilir değişkeni ifade etmektedir. Denklem 4 'de doğrusal bir fonksiyon olarak modellenebilen ve gözlemlenemeyen $f_{t}, g_{t}$ ortak faktörleri, ülkeye özgü faktör yükleri ile $k$ gözlenebilir regresörlerin ampirik bir gösterimiyle oluşturulmuştur. Yatay kesit bağımlılığı gözlenebilir ve gözlemlenemeyen modellerde bu faktörlerin göz önüne alınmasıyla önemli hale gelmektedir.

AMG tahmincisi iki aşama yürütülmektedir:

$\begin{array}{ll}\text { AMG - Aşama (i) } & \Delta y_{i t}=b^{\prime} \Delta x_{i t}+\sum_{t=2}^{T} c t \Delta D_{t}+e_{i t} \Rightarrow \hat{c}_{t \equiv} \hat{u}_{t}^{\bullet} \\ \text { AMG - Aşama } & \text { (ii) } \quad y_{i t}=a_{i}+b_{i}^{\prime} x_{i t}+c_{i} t+d_{i} \hat{u}_{t}^{\bullet}+e_{i t} \Rightarrow\end{array}$

AMG
$\hat{b}_{A M G} N^{-1} \sum_{\mathrm{i}} \hat{b}_{\mathrm{I}}$

Birinci aşamada model, değişenlerin birinci farkı alınarak ve yıl kukla değişkeni eklenerek tahmin edilmektedir. Burada temel amaç, durağan olmayan değişkenlerin ve gözlenemeyen etkilerin hatalara neden olmamasını sağlamaktır. İkinci aşamada ise bu değişken, her bir $\mathrm{N}$ için standart ülke regresyonuna eklenmektedir. Eberhardt ve Bond (2009) tarafından geliştirilen AMG tahmincisi hakkında bilgi verildikten sonra, değişkenler arasında ortalama ve ülkelere özgü uzun dönemli katsayılar bu yöntem ile tahmin edilmiştir. 
Eskişehir Osmangazi Üniversitesi iißBF Dergisi

Tablo 6: Seçilmiş OECD Ülkelerinde AMG Tahmincisi Sonuçları

\begin{tabular}{lcccc}
\hline Değişken & Katsayı & Standart Hata & z İstatistiği & Olasılık \\
\hline \hline LNBY & $-0,032$ & 0,014 & $-2,17$ & $0,030^{* *}$ \\
LNGSYiH & 0,199 & 0,068 & 2,89 & $0,004^{* * *}$ \\
LNPF & $-0,061$ & 0,017 & $-3,44$ & $0,001^{* * *}$ \\
Trend & $-0,002$ & 0,001 & $-1,78$ & $0,075^{*}$ \\
C & 0,033 & 0,008 & 3,91 & $0,000^{* * *}$ \\
CDP1 & 0,999 & 0,218 & 4,57 & $0,000^{* * *}$ \\
\hline \hline
\end{tabular}

Not: Değerlerin yanındaki $*\left(* * * p<0.01,{ }^{* *} p<0.05,{ }^{*} p<0.1\right)$ değişkenlerin anlamlılığını ifade etmektedir. $\left(^{1}\right)$ Yatay kesit bağımlılığı, ortak dinamik etkiler değişkenin analize eklenmesiyle dikkate alınmıştır.

Tablo 6'da analize dahil edilen OECD ülkelerinde değişkenlerin ortalama katsayılarına dair bulgular yer almaktadır. AMG tahmincisine göre, biyoyakıt üretimi, GSYiH, ulaşımda kullanılan petrol tüketimi ve petrol ithalat fiyatı değişkenleri istatistiki ve ekonomik olarak anlamlı bulgular içermektedir. Biyoyakıt üretiminde \% $10^{\prime}$ luk bir artışın, ulaşımda tüketilen petrolü \% 0,32 azaltacağı sonucuna ulaşıımıştır. Bu sonuç, uygulanan biyoyakıt politikalarının petrol tüketimini azaltmada etkin bir araç olduğunu göstermektedir. GSYiH değişkeni ise, ekonomik büyümenin \% 10 arttığı durumda petrol tüketiminin \% 1,9 artacağını ifade etmektedir. Petrol fiyatlarında yaşanacak \% $10^{\prime}$ luk bir artış ise, petrol tüketimini pahalı hale getireceğinden tüketim \% 0,6 azalacaktır.

Tablo 6'da yer alan tahmin sonuçları, ülkelerin ortalamalarını gösterdiğinden yorum yapabilme imkânı kısıtlıdır. Bu nedenle daha detaylı bir analiz yapabilmek için ülkeye özgü katsayı tahminlerine Tablo 7'de yer verilmiştir.

Tablo 7: Seçilmiş OECD Ülkelerine Özgü Katsayılar

\begin{tabular}{|c|c|c|c|c|c|c|}
\hline Ülke & LNBY & LNGSYIH & LNPF & Trend & $\mathrm{C}$ & CDP \\
\hline$A B D$ & $-0,172^{*}$ & $1,100 *$ & $-0,015$ & $-0,005$ & 0,022 & 0,489 \\
\hline Almanya & $-0,055$ & 0,039 & 0,0008 & $0,005 * * *$ & $-0,027$ & $-0,164$ \\
\hline Avustralya & $-0,001$ & $0,129 * *$ & $-0,020$ & $-0,001$ & 0,010 & $0,347 *$ \\
\hline Avusturya & $-0,131$ & 0,129 & $-0,076$ & $-0,007$ & $-0,094$ & 2,166 \\
\hline Belçika & 0,002 & 0,122 & $-0,073$ & $-0,000$ & 0,007 & 0,660 \\
\hline Birleşik Krallık & 0,006 & $0,115^{* * *}$ & $-0,029 * * *$ & $0,003^{* * *}$ & $-0,016^{* *}$ & $0,538 * * *$ \\
\hline Finlandiya & $-0,095 * * *$ & 0,050 & $-0,084$ & $-0,021 * *$ & $0,182 * *$ & $2,717 * * *$ \\
\hline Fransa & $-0,050 * *$ & 0,021 & $-0,021$ & $-0,001$ & 0,015 & $0,485^{* *}$ \\
\hline Güney Kore & $-0,000$ & 0,160 & $-0,070 * *$ & 0,000 & 0,009 & 0,459 \\
\hline Hollanda & $-0,062 * *$ & $-0,148$ & 0,009 & $-0,010^{*}$ & $0,089 *$ & 1,029 \\
\hline İspanya & $-0,046$ & 0,049 & $-0,080$ & $-0,003$ & 0,039 & $2,286 * *$ \\
\hline İsveç & 0,024 & 0,044 & $-0,031$ & 0,001 & $-0,000$ & 1,104 \\
\hline İtalya & $-0,004$ & 0,288 & $-0,030$ & 0,004 & $-0,042$ & 0,350 \\
\hline Kanada & 0,010 & 0,163 & $-0,022$ & $-0,002$ & 0,029 & 0,540 \\
\hline Polonya & 0,032 & 0,117 & $-0,57$ & $-0,004$ & 0,096 & 2,739 \\
\hline Portekiz & $-0,071$ & $0,436^{* *}$ & $-0,134 * * *$ & $-0,005$ & 0,037 & 0,860 \\
\hline Türkiye & 0,063 & 0,564 & $-0,306$ & $-0,000$ & 0,027 & 0,374 \\
\hline
\end{tabular}


Analize dâhil edilen OECD ülkelerinden ABD, Finlandiya, Fransa ve Hollanda biyoyakıt politikalarını en etkin şekilde yürüten ülkelerdir. Katsayıların negatif ve istatistiki olarak anlamlı olması, bulguları destekler niteliktedir. ABD'nin biyoyakıt üretiminde \% 10 düzeyinde bir artış ulaşımda kullanılan petrol tüketimini \% 1,7 azaltmaktadır. Biyoyakıt politikalarını etkin bir şekilde yürüten Finlandiya, Fransa ve Hollanda da bu etki biraz düşük kalmasına rağmen, biyoyakıtların geleceği için umut veren bir görünüm sergilemektedirler. Ülkelere özgü biyoyakıt üretimi değişkeni genel olarak negatif işaretli iken, istatistiki olarak anlamsız olduğu tesbit edilmiştir. Ortalama katsayıları içeren Tablo $6^{\prime}$ da biyoyakıt üretimi değişkeninin negatif ve istatistiki olarak anlamlı olması, ülkeye özgü katsayıların negatif olmasının bir sonucudur.

Yapılan çalışma literatür ile karşılaştırıldığında; Demirbaş (2009) ve Reboredo vd. (2016) ile benzer bulgular elde edilmiştir. Demirbaş (2009), biyoyakıtların çevreye duyarlı olması ve petrole olan bağımlılı̆ı azaltması gibi avantajlarından dolayı potansiyel bir enerji türü olduğunu ifade etmektedir. Reboredo vd. (2016) ise; petrol fiyatları arttığında, petrol tüketiminin azalacağını ve bu nedenle biyoyakıtlarda yaşanan gelişmelerin sürdürüleceğini ifade etmektedirler. Tarafımızca yapılan çalışmanın bulguları da bu yargıları destekler niteliktedir.

\section{Sonuç}

Çalışmada, biyoyakıt politikalarının ulaşım sektöründe tüketilen petrol üzerindeki etkileri seçilmiş OECD ülkeleri örnekleminde yatay kesit bağımlılı̆ı̆ı dikkate alan yöntemlerle analiz edilmiştir. Bulguları güçlendirmek amacıyla petrol ithalat fiyatı ve GSYiH değişkenleri analize dâhil edilmiştir. Günümüz dünyasında bir ülkenin aldığı ekonomik kararın diğer ülkeleri de etkilediği düşünüldüğünde, yatay kesit bağımlılığını dikkate alan yöntemlerin kullanılması çalışma boyunca bir kural olarak benimsenmiştir. Bu kapsamda, yatay kesit bağımlıı̆̆ Friedman (1937) ve Pesaran (2004) testleri ile araştırılmış ve yatay kesitler arasında bir korelasyon olduğu tesbit edilmiştir. Pesaran (2007) birim kök testi ile değişkenlerin durağanlıkları araştırılmış ve değişkenlerin birinci farkı alındığında durağan olduğu sonucuna ulaşılmıştır. Westerlund (2007) eşbütünleşme testi ile ise uzun dönemli ilişkinin varlığı kanıtlamıştır. Uzun dönemli katsayıların tahmini için ise Eberhardt ve Bond (2009) tarafından geliştirilen AMG tahmincisi kullanılmıştır.

Petrol ithalatçısı konumundaki ülkeler, petrol bağımlılıklarını azaltmak amacıyla yerel ve ucuz enerji kaynaklarına ihtiyaç duymaktadır. Biyoyakıt gibi petrole alternatif olabilecek yakıt türlerinin kullanımının son yıllarda yaygınlaşması ve bu yakıt türünün petrol tüketimi üzerindeki etkilerinin araştırıması çalışmanın önemini oluşturmaktadır. Seçilen OECD ülkelerinin petrol açısından ithalata bağımlı olmaları, analiz bulgularının yorumlanması için önemlidir.

AMG tahmincisine göre, OECD ülkelerinde biyoyakıt üretimi artışının ulaşım sektöründe kullanılan petrolü azalttığı sonucuna ulaşılmıştır. Bu sonuç, biyoyakıtların ulaşım sektöründe tüketilen petrolü azaltmada etkin bir politika aracı olarak kullanılabileceğini göstermektedir. Diğer yandan, ülkeler ekonomik olarak büyüdüğünde petrol tüketimlerinde bir artış gerçekleştiği belirlenmiştir. Ancak bu veriler ortalama katsayıları ifade ettiği için ülkelere özgü katsayıların yorumlanması daha anlamlı olmaktadır. Ülkelere özgü katsayılar incelendiğinde, biyoyakıt politikalarını ABD, Finlandiya, Fransa ve Hollanda'nın etkili bir şekilde kullanmakta olduğu görülmüştür. Bu noktada gelişmiş ve gelişmekte olan ülke ayrımının yapılması gerekmektedir.

Gelişmiş ülkeler, cari işlemler dengesinde petrol ürünleri ithalatını düşürebilmek için biyoyakıt ve doğalgaz gibi kaynaklara yönelmektedirler. Ancak bugünkü ulaşım araçları sisteminde aktif olarak petrolün kullanılması ve doğalgazın petrol ürünleri ile ikame edilememesi kullanım 
alanını sınırlamaktadır. Doğalgaz kullanımını ulaşım sektöründe kısıtlayan diğer faktörler ise, petrol gibi fosil kaynaklı bir enerji türü olması, coğrafi olarak erişiminin kıt olması ve ithal edilmesi durumunda cari işlemler dengesini olumsuz etkilemesidir. Biyoyakıtların ise doğrudan petrol ürünleri ile harmanlanabilmesi ve ülkelerin coğrafi özelliklerine göre üreteceği bitki türlerinden elde edilebilmesi, bu enerji türünü ön plana çıkarmaktadır.

Gelişmekte olan ülkelerin yapısı gereği sahip olduğu artan nüfus ve gelişen ekonomik yapı, enerji taleplerini sürekli olarak artırmalarına neden olmaktadır. Gelişmekte olan ülkeler enerji ihtiyaçlarını karşılamak için kaynaklarını çeşitlendirme yolunu izlemektedirler. Bu nedenle, hem petrol ürünleri hem de biyoyakıt türlerine olan talepleri artmakta ve biyoyakıt üretiminde bir artış petrol ürünleri tüketimini azalmamaktadır.

AMG tahmincisinden elde edilen diğer bir bulgu ise, petrol ithalat fiyatlarında yaşanacak bir artışın ulaşımda tüketilen petrolü azaltacağı şeklindedir. 1973 ve 1979'da yaşanan petrol krizleri, tahminciden elde edilen sonuçları desteklemektedir. Petrol fiyatlarının oligopol piyasalarda belirlendiği düşünüldüğünde arz kısıtları, petrolü ithal eden gelişmiş ve gelişmekte olan ülke ekonomilerini doğrudan etkileyebilmektedir. Petrol fiyatlarının artması, petrole alternatif olabilecek yakıtların ucuz hale gelmesini sağlamaktadır. Ancak tersi durumda, petrol maliyet açısından daha kullanılabilir bir kaynak olmakta ve ekonomik dengeleri bozabilmektedir. Ülkeler enerji politikalarını oluştururken bu kriterleri göz önünde bulundurmalı ve biyoyakıt politikalarına ağırlık vererek petrol fiyatlarında yaşanacak bir dalgalanmaya karşı ekonomik istikrarın bozulmamasını sağlamalıdır.

AMG tahmincisinden ulaşılan sonuçlar, hangi ülkelerin örnek alınarak biyoyakıt politikalarının verimli bir şekilde uygulanabileceği hakkında bilgiler içermektedir. $A B$, uzun yıllardan beri ileriye dönük tahminler ve planlamalar yaparak biyoyakıt kullanımını artırmayı hedeflemektedir. AB'nin bu alanda uyguladığı politikaların tutarlı olması, ileriye yönelik olarak yapılan projeksiyon çalışmalarının önemini ortaya koymaktadır. Özellikle Türkiye gibi gelişmekte olan ülkelerin kendi ekonomilerine özgü yapacağı projeksiyon ve hedefleme çalışmaları, AB ülkelerinde olduğu gibi biyoyakıtların kullanımını önemli bir düzeyde artıracaktır.

Bu etkilerin dışında biyoyakıtların kullanımı, kırsal kalkınmaya ve çevresel faktörlere katkı sağlamaktadır. Disiplinler arası çalışmalarla yapılacak araştırmalar ve kamu-özel sektör işbirliği ile sağlanacak teşvikler, kırsal bölgelerde yaşayan kesimin biyoyakıtlar için tarımsal üretim yapmalarını destekleyecektir. Kırsal kesimin gelirindeki artış, kırdan kente göçü engelleyecek ve bölgesel kalkınmaya katkı sağlanacaktır. Ancak bu noktada, enerji arz güvenliği sağlanmaya çalışıırken gıda arz yapısının bozulmamasına dikkat edilmelidir. Biyoyakıt üretmek için tarımı yapılan C4 enerji bitkilerinin (buğday, şeker, aspir, kanola vb.) sadece ulaşım sektöründe kullanılması amacıyla Ar-Ge uygulamaları ile genetiği değiştirilerek daha verimli hale getirilmesi, hem enerji hem de gıda arz güvenliğine katkı sağlayacaktır. 


\section{Kaynaklar}

Akalın, Burcu; Seyrekbasan, Anı M. (2015), “Dünyadaki Biyoetanol Politikalarının Türkiye Koşulları ile Karşılaştırmalı İncelenmesi ve Türkiye Şartlarına Uygunluk Açısından Biyoetanol Üretiminde Kullanılan Hammaddelerin Değerlendirilmesi", Uludağ Üniversitesi Ziraat Fakültesi Dergisi, C. 27, S. 1: 157-168.

Al-Mulali, Usama; Solarin, Sakiru Adebola; Ozturk, Ilhan (2016), "Biofuel Energy Consumption-Economic Growth Relationship: An Empirical Investigation of Brazil", Biofuels, Bioprod. Bioref, Vol. 10: 753-775.

Bai, Jushan; Ng, Serena (2004), “A Panic Attack on Unit Roots and Cointegration”, Econometrica, Vol. 72, No. 4: 11271177.

Banco Nacional de Desenvolvimento Econômico e Social (BNDES); Centro de Gestão e Estudos Estratégicos (CGEE) (2008), "Sugarance-Based Bioethanol: Energy for Sustainable Development", http://www.globalbioenergy.org/uploads/media/0811_BNDES_CGEE_-_Sugarcane-

based_bioethanol_energy_for_sustainable_development.pdf, (Erişim: 23.12.2018).

Bayraç, Hüseyin Naci (2005), "Uluslararası Petrol Piyasasının Ekonomik Analizi", http://www.tek.org.tr/dosyalar/BAYRAC-ENERGY.pdf, (Erişim: 18.11.2018).

Bayraç, Hüseyin Naci (2010), "Enerji Kullanımının Küresel Isınmaya Etkisi ve Önleyici Politikalar", Eskişehir Osmangazi Üniversitesi Sosyal Bilimler Dergisi, C. 11, S. 2: 241-245.

Bayraç, Hüseyin Naci; Çemrek, Fatih (2018), “Avrupa Birliği ve Türkiye'de Biyoetanol Üretiminin Ekonomik Büyüme Üzerindeki Etkisinin Araştırılması”, III. Uluslararası Sosyal Bilimler Araştırmaları Kongresi, 05-08 Eylül 2018 ÜsküpMakedonya, Bildiriler Kitabı, (Editörler: Kara, H.-Çetin, T.-İnel, Y.), ISBN: 978-605-82037-3-0, ANKAD Yayınları: 121-133.

Bayraç, Hüseyin Naci; Güllü, Mustafa (2017), “Biyoyakıt Üretimi, Karbon Emisyonu ve Ekonomik Büyüme İlişkisi: Amerika, Brezilya ve Almanya Örnekleri", Akademik Bakış Uluslararası Hakemli Sosyal Bilimler Dergisi, S. 64: 1834.

Bildirici, Melike (2017), "Impact of Militarization and Economic Growth on Biofuels Consumption and $\mathrm{CO}_{2}$ Emissions: The Evidence from Brazil, China, and US", Environmental Progress \& Sustainable Energy, Vol. 37, No. 3: 11211131.

BP Statistical Review of World Energy (2018), https://www.bp.com/content/dam/bp/en/corporate/pdf/energyeconomics/statistical-review/bp-stats-review-2018-full-report.pdf, (Erişim 22.12.2018).

Choi, In (2001), “Unit Root Tests for Panel Data”, Journal of International Money and Finance, Vol. 20, No. 2: 249-272.

Demirbas, Ayhan (2009), "Political, Economic and Environmental Impacts of Biofuels: A Review", Applied Energy, Vol. 86: 108-117.

Eberhardt, Markus; Bond, Stephen (2009), “Cross-Section Dependence in Non-Stationary Panel Models: A Novel Estimator", Munich Personal Repec Archive Paper Series, No: 17692.

EC (2003), "Directive 2003/30/EC of the European Parliament and of the Council of 8 May 2003 on The Promotion of the Use of Biofuels or Other Renewable Fuels for Transport", https://eur-lex.europa.eu/legalcontent/EN/TXT/PDF/?uri=CELEX:32003L0030\&from=en, (Erişim: 02.01.2019).

EC (2009), "Directive 2009/28/EC of the European Parliament and of the Council Of 23 April 2009 on the Promotion of the Use of Energy from Renewable Sources and Amending and Subsequently Repealing Directives 2001/77/EC and 2003/30/EC", https://eur-lex.europa.eu/legal-content/EN/TXT/PDF/?uri=CELEX:32009L0028\&from=EN, (Erişim : 02.01.2019).

Friedman, Milton (1937), "The Use of Ranks to Avoid the Assumption of Normality Implicit in the Analysis of Variance", Journal of the American Statistical Association, Vol. 32, No. 200: 675-701.

Gujarati, Damodar N.; Porter, Dawn C. (2009), Basic Econometrics $5^{\text {th }}$ Ed., New York: McGraw-Hill / Irwin.

Harlander, Katharina (2008), "Food vs. Fuel- A Turning Point for Bioethanol?”, Acta Agronomica Hungarica, Vol. 56, No. 4: 429-433.

Hatunoğlu, E. Emrah (2010), "Biyoyakıt Politikalarının Tarım Sektörüne Etkileri”, DPT. iktisadi Sektörler ve Koordinasyon Genel Müdürlüğü, Yayın No: 2814.

Horuz, Ayhan; Korkmaz, Ahmet; Akınoğlu, Güney (2015), "Biyoyakıt Bitkileri ve Teknolojisi”, Toprak Bilimi ve Bitki Besleme Dergisi, C. 3, S. 2: 69-81. 


\section{Eskişehir Osmangazi Üniversitesi IïB Dergisi}

http://biofuelsassociation.com.au/policy/world-biofuel-policies/, (Erişim: 05.01.2019).

http://www.yegm.gov.tr/yenilenebilir/biyokutle_enerjisi_adv.aspx, (Erişim: 12.11.2018).

Im, Kyung So; Pesaran, M. Hashem; Shin, Yongcheol (2003), "Testing for Unit Roots in Heterogeneous Panels", Journal of Econometrics, Vol. 115, No. 1: 53-74.

International Energy Agency (2018), "IEA World Energy Balances", https://www.iea.org/statistics, (Erişim: 28.12.2018).

Janda, Karel; Kristoufek, Ladislav; Zilberman, David (2011), "Biofuels: Review of Policies and Impacts", Cudare Working Papers, No: 1119.

Kar, Suraj; Kumar, Rakesh; Singh, Magan; Soni, Pooja Gupta; Makarana, Govind; Joshi, Deepa; Kushwaha, Manish (2017), " $C_{4}$ Photosynthesis and Biomass", International Journal of Current Microbiology and Applied Sciences, Vol. 6, No. 3: 1567-1574.

Levin, Andrew; Lin, Chien-Fu; Chu, Chia-Shang James (2002), “Unit Roots Tests in Panel Data: Asymptotic and Finite Sample Properties", Journal of Econometrics, Vol. 108, No. 1: 1-24.

Maddala, Gangadharrao Soundalyarao; Wu, Shaowen (1999), “A Comparative Study of Unit Root Tests with Panel Data and a New Simple Test", Oxford Bulletin of Economics and Statistics, Vol. 61, No. S1: 631- 652.

Moon, Hyungsik Roger; Perron, Benoit (2004), "Testing for a Unit Root in Panels with Dynamic Factors", Journal of Econometrics, Vol. 122, No. 1: 81-126.

OECD (2019), "Crude Oil Import Prices (Indicator)", doi: 10.1787/9eeOe3ab-en, (Erişim: 03.01.2019).

Özertan, Gökhan (2008), “Biyoyakıtların Türkiye'nin Enerji, Tarım, Çevre Ve Kırsal Kalkınma Politikaları İçin Önemi”, iktisat Işletme ve Finans, C. 23, S. 262: 17-34.

Pesaran, M. Hashem (2004), “General Diagnostic Tests for Cross Section Dependence in Panels”, Center for Economic Studies \& Ifo Institute for Economic Research Working Paper, No. 1229.

Pesaran, M. Hashem (2007), "A Simple Panel Unit Root Test in The Presence of Cross Section Dependence", Journal of Applied Econometrics, Vol. 22, No. 2: 265-312.

Phillips, Peter C. B.; Sul, Donggyu (2003), "Dynamic Panel Estimation and Homogeneity Testing Under Cross Section Dependence", The Econometrics Journal, Vol. 6, No. 1: 217-259.

Reboredo, Fernando H.; Lidon, Fernando; Pessoa, Fernanda; Ramalho, José C. (2016), "The Fall of Oil Prices and the Effects on Biofuels", Trends in Biotechnology, Vol. 34, No. 1: 3-6.

Simionescu, Mihaela; Albu, Lucian-Liviu; Szeles, Monica Raileanu; Bilan Yuriy (2017), "The Impact of Biofuels Utilisation in Transport on the Sustainable Development in The European Union", Technological And Economic Development of Economy, Vo. 23, No. 4: 667-686.

Soon, Lim Eui (2015), "Current Status of Polices Transportation Biofuels in Key Countries", http://eneken.ieej.or.jp/data/6380.pdf, (Erişim: 21.11.2018).

The World Bank (2018), "World Development Indicators, GDP Current \$", https://data.worldbank.org/indicator/NY.GDP.MKTP.CD, (Erişim: 26.12.2018).

Westerlund, Joakim (2007), "Testing for Error Correction in Panel Data", Oxford Bulletin of Economics and Statistics, Vol. 69, No. 6: 709-748.

Westerlund, Joakim; Edgerton, David L. (2008), "A Simple Test for Cointegration in Dependent Panels with Structural Breaks", Oxford Bulletin of Economics and Statistics, Vol. 70, No. 5: 665-704. 
Extended Summary

\section{The Effect of Biofuels Policies on Oil Consumption in the Transportation Sector in OECD Countries}

Biomass is one of the renewable energy sources with the highest potential. As biomass is a local and easily accessible type of energy, countries have the potential to reduce fossil fuel dependence with these characteristics. Biomass can be converted into electrical-heat energy, fuel in transportation and chemical raw materials. The energy obtained from biomass and used in transportation is called biofuel (bioethanol and biodiesel). We only discuss biofuels from biomass energy types in this paper.

To measure the effectiveness of biofuel policies, it is examined whether biofuels reduce the consumption of oil products in the transportation sector. Economic growth and population growth are the main factors determining the energy demand in the transportation sector. Economic growth increases industrial output, which makes it necessary for raw materials to be transported to industrial manufacturers and the final product to end users. Urbanization and the increase in personal income are another important factor that increases the energy demand for transportation. In the coming years, the energy demand for transportation is expected to increase in both OECD and non-OECD countries and this idea emphasizes the importance of the study.

We select OECD countries as an example of the study because they are among the world's largest economies with 36 members. According to the classification of the World Bank, they locate in developed countries group (excluding Hungary, Turkey and Mexico), and because of this characteristic they have the power to dominate international energy markets. In addition to this, significant part of the world's biofuel production/consumption process is realized in OECD countries.

The aim of this study is to investigate the effects of biofuel use on petroleum consumption in selected OECD countries. The hypotheses that we have created for this purpose are: (1) 'there is a long-run relationship between the variables' and (2) 'an increase in biofuel production reduces oil consumed in transportation'. We use Westerlund Cointegration and Augmented Mean Group (AMG) methods for testing these hypotheses. The reason for using these methods is to take into account the cross-sectional dependence and thus to reach more accurate results. In addition, the AMG method can estimate country-specific coefficients. In this way, country-specific coefficient estimation deepens the analysis result and makes the study more original.

We implement the analysis for 17 OECD countries (USA, Germany, Australia, Austria, Belgium, United Kingdom, Finland, France, South Korea, Netherlands, Spain, Sweden, Italy, Canada, Poland, Portugal, Turkey) between the periods 2006-2016. We include oil import price and GDP, which are among the factors affecting oil consumption, as auxiliary variables to the analysis. In this study, after discussing energy agriculture concept and energy agriculture policies, biofuel policies applied in OECD countries and studies in the literature are included. Afterwards, we pass to data analysis process.

In the literature, there are no studies investigating the effect of biofuel policies on oil used in transportation sector. In these studies, general evaluations about the economic, political and environmental impacts of biofuels are discussed. In some studies, the relationship between economic growth and biofuel production-consumption is examined. Therefore, our paper presents a new approach to the effectiveness of biofuel policies and differs from the studies in the literature.

Oil consumption in the transportation sector, biofuel production, oil import price and GDP variables are obtained from International Energy Agency (IEA), British Petroleum (BP), OECD and World Bank (WB), respectively. All variables are converted to natural logarithmic form to ensure normalization.

The analysis consists of four stages. These stages are; testing cross-sectional dependence, the determination of the presence of the unit root, the long-term relationship and the coefficient estimate for this long-run relationship. Friedman (1937) and Pesaran (2004) methods are used for the determination of cross-sectional dependence, Pesaran (2007) for the panel unit root test, Westerlund (2007) for the long-run relationship and AMG method for the long-run coefficient estimation.

Friedman (1937) and Pesaran (2004) tests show that there is a strong relationship between cross-sections, and therefore it is concluded that using first generation unit root tests may cause error in the model. For this reason, we decide to apply Pesaran (2007) test, which is one of the second-generation panel unit root tests, to establish the model correctly. According to unit root test results, biofuel production, oil consumed in transportation sector, oil import price and GDP are become stable when the first differences are taken. 


\section{Eskişehir Osmangazi Üniversitesi IïBF Dergisi}

After determining that the model is established correctly, we implement Westerlund (2007) cointegration test, and we find long-run relationship between the variables. This result proves that the hypothesis (there is a long-run relationship between the variables) is valid for OECD countries. According to the results of the AMG method for the estimation of long-run coefficients, an increase in biofuel production decreases the oil consumption used in transportation. This result proves the expression stated in hypothesis 2 . When we look to the country-specific coefficients for a more comprehensive analysis, we find that the hypothesis 2 valid for United States, Finland, France and Netherlands.

These results show that biofuels can be used as an effective policy tool to reduce the oil consumption in the transportation sector. The use of biofuels contributes to rural development and environmental factors. Interdisciplinary studies and incentives to be provided by public-private sector cooperation will support the agricultural production of biofuels in rural areas. The increase in rural income will prevent migration from rural to urban areas and contribute to regional development. 